\begin{tabular}{c|c}
\hline \hline JURNAL SAINS dan INOVASI PERIKANAN \\
Journal of Fishery Science and Innovation \\
e-ISSN: 2502-3276 \\
Vol. 4, No.2, 74-82, Juli 2020 \\
http://ojs.uho.ac.id/index.php/JSIPi \\
\hline
\end{tabular}

\title{
Potensi Ekstrak Daun Mangrove Rhizophora mucronata dan Avicennia Officinalis sebagai Bahan Pembuatan Serbuk Effervescent
}

\section{Potency Mangrove Leaf Extract of Rhizophora mucronata and Avicennia officinalis as Material for Making Effervescent Powder}

\author{
Nirmala Efri Hasibuan ${ }^{\left.1)^{*}\right)}$, Sumartini ${ }^{1)}$ \\ ${ }^{1)}$ Program Studi Pengolahan Hasil Laut, Politeknik Kelautan dan Perikanan Dumai, Kota Dumai, Indonesia \\ Corresponding author ${ }^{*}$ : nirmala.efrihsb@gmail.com
}

\begin{abstract}
Rhizophora mucronata and Avicennia officinalis are mangrove species that have high bioactive content potential. In this study dried mangrove leaf extract was used as a source of active substances in effervescent. Effervescent granules of mangrove leaf extracts using the wet granulation method. The purpose of this research was to formulate effervescent granules of mangrove leaf extract from mangrove species R.mucronata and A. officinalis and to determine the effect of levels differences of mangrove leaf extracts on the physical characteristics of effervescent granules. Effervescent granules of mangrove leaf extract are made in five formulations by varying the levels of mangrove leaf extract. Effervescent granules are prepared in five formulations by varying the levels of mangrove leaf extracts. Characteristics effervescent granules of mangrove leaf extract produced have brownish yellow, $\mathrm{pH}$ 5.05-5.81, moisture content 2.042-2.809\%, soluble time 62.33 - 91, 33 seconds, tannin content $2.59-3.91 \%$ and phenol content $1,69-3.86 \%$. The results showed there were no significant differences in various species of mangrove leaf however the differences of formulation showed there were significant with the characteristics of mangrove leaves powder effervescent. Based on result showed that mangrove leaf have a potencial for effervescent drink because of his phenol and tannin content.
\end{abstract}

Keywords : Rhizophora mucronata, Avicennia officinalis, Effervescent

\begin{abstract}
ABSTRAK
Rhizophora mucronata dan Avicennia officinalis merupakan jenis mangrove yang memiliki potensi kandungan bioaktif yang tinggi. Dalam penelitian ini ekstrak daun mangrove kering dimanfaatkan sebagai sumber zat aktif pada effervescent. Pembuatan granul effervescent ekstrak daun mangrove menggunakan metode granulasi basah. Tujuan penelitian ini adalah untuk memformulasikan granul effervescent ekstrak daun mangrove dari spesies mangrove R.mucronata dan A officinalis dan untuk mengetahui pengaruh perbedaan kadar ekstrak daun mangrove terhadap karakteristik fisik granul effervescent. Granul effervescent ekstrak daun mangrove dibuat dalam lima formulasi dengan memvariasikan kadar ekstrak daun mangrove. Granul effervescent ekstrak daun mangrove yang dihasilkan memiliki karakteristik berwarna kuning kecoklatan, pH 5.05-5.81, kadar air 2,042 2,809\%, waktu larut 62,33 - 91, 33 detik, kadar tanin 2,59 - 3,91\% dan kadar fenol 1,69 - 3,86\%. Hasil penelitian menunjukkan tidak ada perbedaan signifikan spesies daun mangrove terhadap karakteristik serbuk effervescent sedangkan formulasi yang berbeda menunjukkan perbedaan signifikan dari karakteristik serbuk effervescent daun mangrove. Hal ini menunjukkan bahwa daun mangrove memiliki potensi digunakan sebagai minuman effervescent karena memiliki kandungan fenol dan tanin.
\end{abstract}

Kata Kunci : Rhizophora mucronata, Avicennia officinalis, Effervescent

DOI: http://dx.doi.org/10.33772/jsipi.v4i2.12667 


\section{PENDAHULUAN}

Tanaman mangrove merupakan tanaman yang tumbuh subur di wilayah pesisir pantai dan memiliki potensi pemanfaatan yang tinggi dalam berbagai bidang disebabkan oleh adanya kandungan senyawa bioaktif. Indonesia memiliki kawasan perairan yang luas sehingga tanaman ini tersebar di seluruh wilayah di Indonesia. Tanaman mangrove terdiri dari 202 jenis yang telah diketahui, diantaranya Rhizophora mucronata, Bruguiera cylindric, Avicennia alba, A.officinalis, Kandelia candel, Sonneratia alba, dan Xylocarpus australasicus (Noor et al., 2006). Ridlo et al. (2017) dalam menyatakan bahwa daun R.mucronata mengandung senyawa metabolit sekunder seperti tanin, karotenoid, fenol, klorofil dan alkaloid. Handayani (2013) menyatakan bahwa ekstrak kasar daun A. marina mengandung senyawa bioaktif tanin, alkaloid, steroid/ triterpenoid dan flavonoid. Ekstrak daun tanaman mangrove jenis R.mucronata dan $A$ officinalis yang kaya antioksidan dalam penelitian ini digunakan sebagai bahan baku pembuatan effervescent.

Effervescent terdiri dari jenis tablet dan granul/serbuk. Effervescent merupakan sediaan yang bersifat mengeluarkan gas setelah penambahan bahan cair lain. Prinsip dasar pembentukannya dengan mereaksikan senyawa asam organik dengan garam organik. Asam sitrat ditambahkan natrium bikarbonat sehingga menghasilkan natrium sitrat dan gas $\mathrm{CO}_{2}$ (Lazuardi, 2019).

Syamsul \& Supomo (2014) melakukan formulasi effervescent dengan penambahan ekstrak bawang tiwai sebagai sumber antioksidan. Effervescent pada dasarnya disukai karena mempunyai warna, rasa dan bau yang menarik. Effervescent dengan penambahan zat antioksidan alami memberikan nilai unggul sebagai minuman yang menarik dan sehat.

Egeten, et al. (2016) telah melakukan penelitian yang bertujuan untuk membuat formulasi granul effervescent dari sari buah nanas. Hasil penelitian menunjukkan sifat fisik sediaan granul effervescent yang dihasilkan di pengaruhi oleh konsentrasi asam dan basa yang berbeda. Penambahan sari buah nenas berperan sebagai sumber antioksidan.

Romantika et al. (2017) telah melakukan penelitian formulasi effervescent dengan memvariasikan persentase asam sitrat dan bubuk jeruk baby java. Hasil penelitian menunjukkan komposisi asam sitrat dan bubuk jeruk baby java berpengaruh terhadap sifat fisik dan kimia effervescent. Penambahan bubuk jeruk baby java menjadi sumber vitamin $C$ yang berperan sebagai antioksidan pada effervescent. Setiana \& Kusuma (2018) telah mereview jurnal terkait formulasi granul effervescent dari berbagai tumbuhan. Ekstrak daun mangrove R. mucronata digunakan sebagai salah satu sumber alami tanin dan flavonoid dan diaplikasikan dalam pengobatan tradisional sebagai obat diare (Puspitasar, 2012). Selain itu, Mikchaell (2018) juga menyatakan bahwa ekstrak daun mengrove R. mucronata memiliki aktivitas antibakteri dikarenakan mengandung senyawa flavonoid dan tanin.Diketahui bahwa ekstrak daun mangrove memiliki potensi dalam peningkatan nilai aktivitas antibakteri, antioksidan dan sebagai tambahan obat tradisional. Hasil review menunjukkan bahwa tanaman sebagai sumber zat aktif dapat menjadi sediaan granul effervescent sehingga berperan dalam pengembangan obat herbal baru yang dapat bermanfaat bagi masyarakat.

Tujuan penelitian adalah memformulasikan granul effervescent ekstrak daun mangrove dari spesies mangrove $R$. mucronata dan $A$. officinalis dan untuk mengetahui pengaruh perbedaan kadar ekstrak daun mangrove terhadap karakteristik fisik granul effervescent. Granul effervescent ekstrak daun mangrove dibuat dalam lima formulasi dengan memvariasikan kadar ekstrak daun mangrove. Dalam penelitian ini dilakukan penambahan ekstrak daun mangrove sebagai suatu inovasi effervescent yang kaya antioksidan alami serta menambah nilai ekonomis dari daun mangrove.

\section{METODE PENELITIAN}

Alat yang digunakan adalah gelas (pyrex) untuk analisa, oven (memmert), desikator (Duran), pH meter (Inolab WTW Series), ayakan saringan berukuran 20 mesh.

Bahan yang digunakan dalam penelitian ini antara lain daun mangrove R.mucronata dan $A$ officinalis kering, pengemulsi karboksimetil selulosa (CMC) (koepoe-koepoe), acesulfam-K (Indo Food Chem), essence (Smelling good), asam sitrat (koepoe-koepoe), asam tartrat(p.a merck), natrium benzoat (koepoe-koepoe), natrium bikarbonat (Asahi), maltodextrin (Indo 
Food Chem) dan sucralose (Kanbo sucralose).

\section{Preparasi Ekstrak Daun Mangrove}

Morfologi daun mangrove A.officinalis dan R. mucronata dapat dilihat pada Gambar 1 . Daun A.officinalis (Gambar 1 a) memiliki permukaan atas berwarna hijau tua dan bagian bawah berwarna hijau-kekuningan atau abu-abu kehijauan. Sejumlah bintik-bintik kelenjar berbentuk cekung menutupi bagian sisi atas daun. Unit dan letaknya sederhana dan berlawanan. Berbentuk bulat telur terbalik, bulat memanjang-bulat telur terbalik atau elips bulat memanjang. Pada ujung membundar,serta menyempit ke arah gagang, beruran daun sekitar $12,5 \times 6 \mathrm{~cm}$.

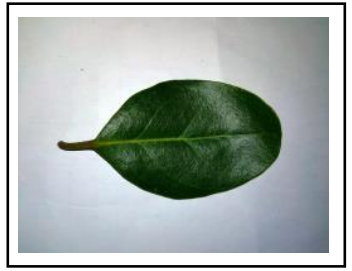

a

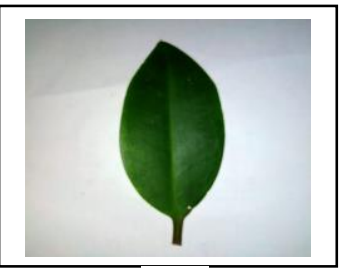

b
Gambar 1. Morfologi daun (a) Avicennia officinalis dan (b) Rhizophora mucronata

Sedangkan daun R.mucronata (Gambar 1 b) memiliki ciri-ciri yaitu gagang daun berwarna hijau dengan panjang mencapai 2,5-
$5,5 \mathrm{~cm}$. Pinak daun terletak pada pangkal gagang daun berukuran sekitar 5,5-8,5 cm. Unit dan letak daun sederhana \& berlawanan. Mempunyai bentuk elips melebar hingga bulat memanjang dengan ujung meruncing. Ukuran daun sekitar $11-23$ x 5-13 cm.

Daun mangrove dirajang dan dikeringkan di bawah sinar matahari, kemudian digiling hingga ukuran partikel 20 mesh. Tahap selanjutnya adalah ekstraksi. Ekstraksi menggunakan metode maserasi dengan pelarut polar yaitu alkohol $70 \%$. Perbandingan bahan dan pelarut yang digunakan adalah 1:4 selama 1 malam. Kemudian dilakukan penyaringan, filtrat dievaporasi menggunakan evaporator hingga diperoleh ekstrak kental dengan viskositas 30- $40 \mathrm{cp}$. Penentuan kekentalan ekstrak daun mangrove dengan menggunakan alat viskometer.

\section{Pembuatan Granul Effervescent}

Pembuatan granul effervescent menggunakan metode granulasi basah. Proses pembuatan granul effervescent dapat dilihat pada Gambar 2. Proses granulasi komponen asam dan komponen basa dilakukan secara terpisah. Formula yang dibuat menggunakan komposisi formula minuman effervescent seperti tertera pada Tabel 1 .

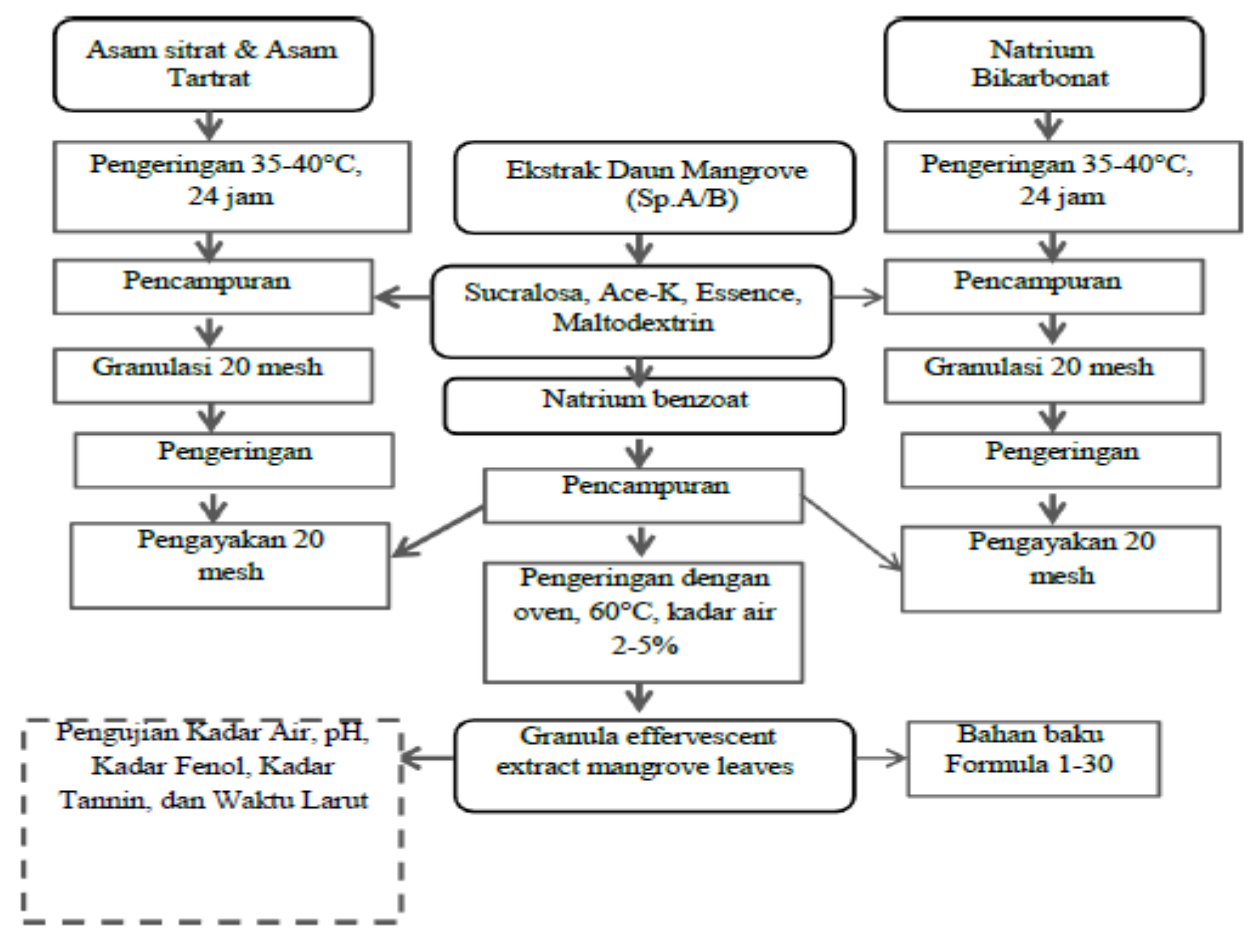


Nirmala Efri Hasibuan et al.

JURNAL SAINS dan INOVASI PERIKANAN / Journal of Fishery Science and

Innovation

Vol. 4, No. 2, 74-82, Juli 2020

Gambar 2. Diagram Alir Proses Pembuatan Granul Effervescent Ekstrak Daun Mangrove (Kailaku et al., 2012)

Tabel 1. Formula Granul Effervescent Mangrove

\begin{tabular}{|c|c|c|c|c|c|c|}
\hline \multirow{2}{*}{$\begin{array}{l}\text { Komponen penyusun } \\
\text { formula }\end{array}$} & \multirow{2}{*}{ Jenis bahan } & \multicolumn{5}{|c|}{ Formula $(\%)$} \\
\hline & & 1 & 2 & 3 & 4 & 5 \\
\hline Zat pengisi/filler & Maltodextrin & 2 & 2 & 2 & 2 & 2 \\
\hline Bahan utama & Daun Mangrove A/B & 15 & 15 & 15 & 20 & 20 \\
\hline Emulsifier & $\mathrm{CMC}$ & 1 & 1,5 & 1 & 1,5 & 1,5 \\
\hline \multirow[t]{2}{*}{ Zat Asam } & Asam Sitrat & 11 & 11 & 11 & 11 & 11 \\
\hline & Asam Tartrat & 14 & 14 & 14 & 14 & 14 \\
\hline \multirow[t]{2}{*}{ Zat Basa } & Natrium Benzoat & 0,06 & 0,06 & 0,06 & 0,06 & 0,06 \\
\hline & Natrium Bikarbonat & 25 & 25 & 25 & 25 & 25 \\
\hline \multirow[t]{2}{*}{ Pemanis } & Sucralose & 15,8 & 15,4 & 11,7 & 11,3 & 11,5 \\
\hline & Acesulfam & 5,2 & 5,1 & 3,9 & 3,7 & 3,2 \\
\hline Pelarut & Air & 32 & 33 & 32 & 28 & 28 \\
\hline Total & & 100 & 100 & 100 & 100 & 100 \\
\hline
\end{tabular}

Granulasi komponen basa berdasarkan pengeringan natrium bikarbonat pada suhu 35$40^{\circ} \mathrm{C}$ selama 24 jam, selanjutnya ditambahkan natrium benzoat, ekstrak daun mangrove, maltodextrin,sucralose, CMC, essence dan acesulfam-K dilanjutkan pengadukan hingga kalis dan digranulasi menggunakan ayakan berukuran 20 mesh.

Pada granulasi komponen asam yaitu asam sitrat dan asam tartrat dikeringkan pada suhu 35-40 ${ }^{\circ} \mathrm{C}$ selama 24 jam, selanjutnya ditambahkan ekstrak daun mangrove, maltodextrin, sucralose, CMC, essence dan acesulfam-K. Campuran diaduk hingga homogen, kemudian disaring dengan ayakan berukuran 20 mesh. Setelah digranulasi masingmasing komponen asam dan basa dikeringkan menggunakan metode oven pada suhu $60^{\circ} \mathrm{C}$ sampai kadar air 2-5\%. Setelah diperoleh granul kering maka kedua komponen digabungkan lalu di saring kembali dengan ayakan 20 mesh.Selanjutnya dilakukan analisis pH (SNI 6989.11: 2019), kadar air (Winarno. 2002), kadar tanin (Chanwitheesuk, 2004), kadar fenol (Lachman, et al., 2006) dan waktu larut granul (Kartikasari, 2015) effervescent yang dihasilkan. Pengolahan data dilakukan menggunakan rancangan acak lengkap (RAK) dilanjutkan analisis ragam (analysis of variance atau ANOVA).

\section{HASIL DAN PEMBAHASAN}

\section{Hasil}

Granul effevescent telah diformulasikan dengan menggunakan dua jenis daun mangrove yaitu $R$. mucronata dan A.officinalis. Granul effervescent berwarna kuning kecoklatan. Hasil penelitian menunjukkan bahwa $\mathrm{pH}$ granul effervescent dari lima formulasi dua spesies mangrove yaitu 5.05-5.81 (Gambar 3). Kadar air granul effervescent ekstrak daun mangrove yang diperoleh yaitu 2,042 sampai 2,809\% (Gambar 4). Waktu larut effervescent berkisar antara 62,33 sampai 91,33 detik (Gambar 5). Hasil uji kadar tanin menunjukkan bahwa granul effervescent daun mangrove jenis Rhizophora mucronata dan Avicennia officinalis berkisar antara 2,59 sampai 3,91\% (Gambar 6). Kadar fenol dalam granul effervescent ekstrak daun mangrove berkisar antara 1,69 sampai 3,86\% (Gambar 7).

\section{Pembahasan}

Ekstrak daun mangrove Rhizophora sp. memiliki potensi yang luas dalam bidang pengobatan tradisional. Hal ini disebabkan ekstrak daun mangrove Rhizophora sp. memiliki kandungan senyawa bioaktif berupa terpenoid, flavonoid, saponin, alkaloid, dan tanin (Wahyuni, et al., 2015). Dalam penelitian ini effervescent telah dibuat dengan menambahkan ekstrak daun mangrove dengan beberapa formulasi. Karakteristik fisik effervescent dapat diketahui dengan melakukan pengukuran pada beberapa parameter. Derajat keasaman, kadar air dan waktu larut menjadi beberapa parameter penting dalam pembuatan effervescent. Diagram derajat keasaman pada Gambar 3 menunjukkan nilai F2A dan F2B memiliki nilai $\mathrm{pH}$ paling rendah yaitu 5.06 dan 5.05 sedangkan F4A dan F1B dengan $\mathrm{pH}$ 
tertinggi yaitu 5.81. Berdasarkan kategori derajat keasaman, granul effervescent yang dihasilkan termasuk kategori bahan pangan berasam rendah. $\mathrm{pH}$ larutan effervescent penting untuk diperhatikan karena apabila $\mathrm{pH}$ terlalu rendah akan menyebabkan iritasi lambung dan $\mathrm{pH}$ yang terlalu tinggi akan menimbulkan rasa pahit (Kailaku et al., 2012).

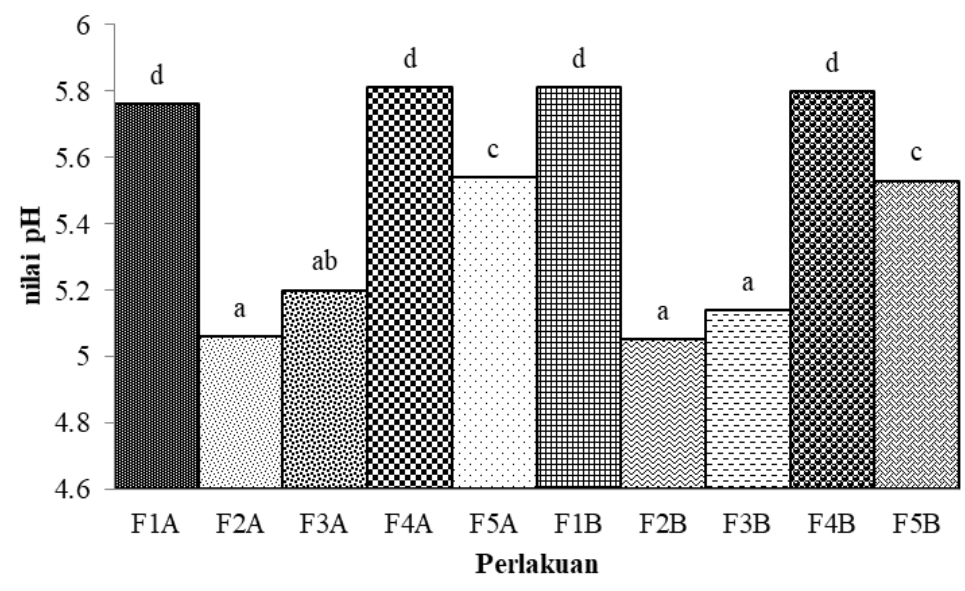

Gambar 3. Digram Derajat Keasaman $(\mathrm{pH})$

Keterangan : huruf superscript yang sama pada diagram menunjukkan tidak ada perbedaan signifikan antara nilai $\mathrm{pH}$ dengan formulasi dan jenis spesies daun bakau $(\mathrm{P}>0,05)$

$\begin{array}{llll}\text { F1A } & : & \text { R. mucronata formulasi 1 } & \text { F1B: A. officinalis formulasi } 1 \text { sesuai Tabel } 1 \\ \text { F2A } & : & \text { R. mucronata formulasi } 2 & \text { F2B: A. officinalis formulasi } 2 \text { sesuai Tabel } 1 \\ \text { F3A } & : & \text { R. mucronata formulasi 3 } & \text { F3B: A. officinalis formulasi } 3 \text { sesuai Tabel } 1 \\ \text { F4A } & : & \text { R. mucronata formulasi 4 } & \text { F4B: A. officinalis formulasi } 4 \text { sesuai Tabel 1 } \\ \text { F5A } & : & \text { R. mucronata formulasi 5 } & \text { F5B: A. officinalis formulasi } 5 \text { sesuai Tabel } 1\end{array}$

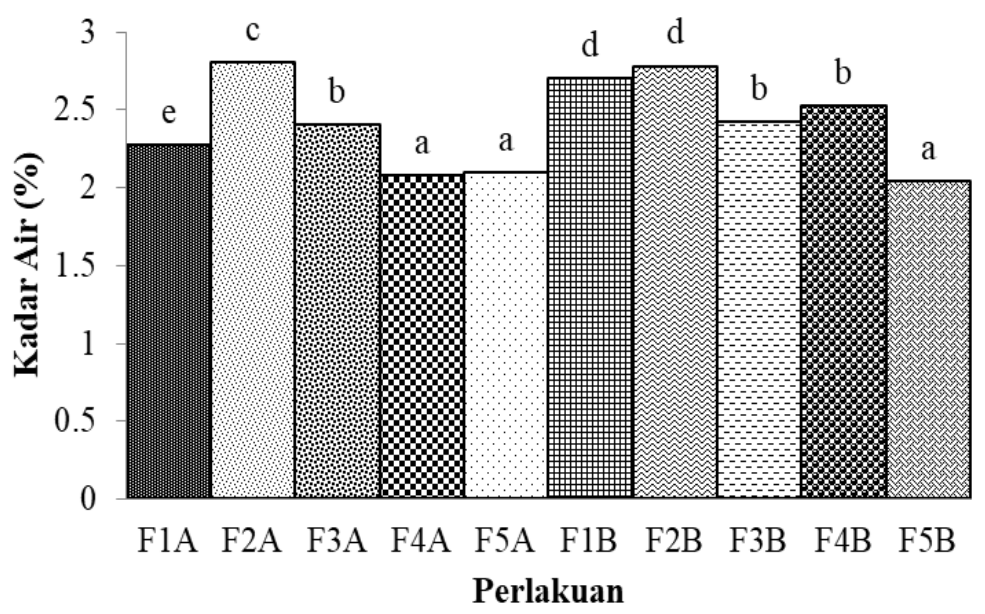

Gambar 4. Diagram Kadar Air Granul Effervescent Ekstrak Daun Mangrove

Keterangan : huruf superscript yang sama pada diagram menunjukkan tidak ada perbedaan signifikan antara nilai kadar air dengan formulasi dan jenis spesies daun bakau $(\mathrm{P}>0,05)$
F1A R. mucronata formulasi 1
F1B: A. officinalis formulasi 1 sesuai Tabel 1
F2A
R. mucronata formulasi 2
F2B: A. officinalis formulasi 2 sesuai Tabel 1
F3A
R. mucronata formulasi 3
F3B: A. officinalis formulasi 3 sesuai Tabel 1
F4A
R. mucronata formulasi 4
F4B: A. officinalis formulasi 4 sesuai Tabel 1
F5A
R. mucronata formulasi 5
F5B: A. officinalis formulasi 5 sesuai Tabel 1 
Vol. 4, No. 2, 74-82, Juli 2020

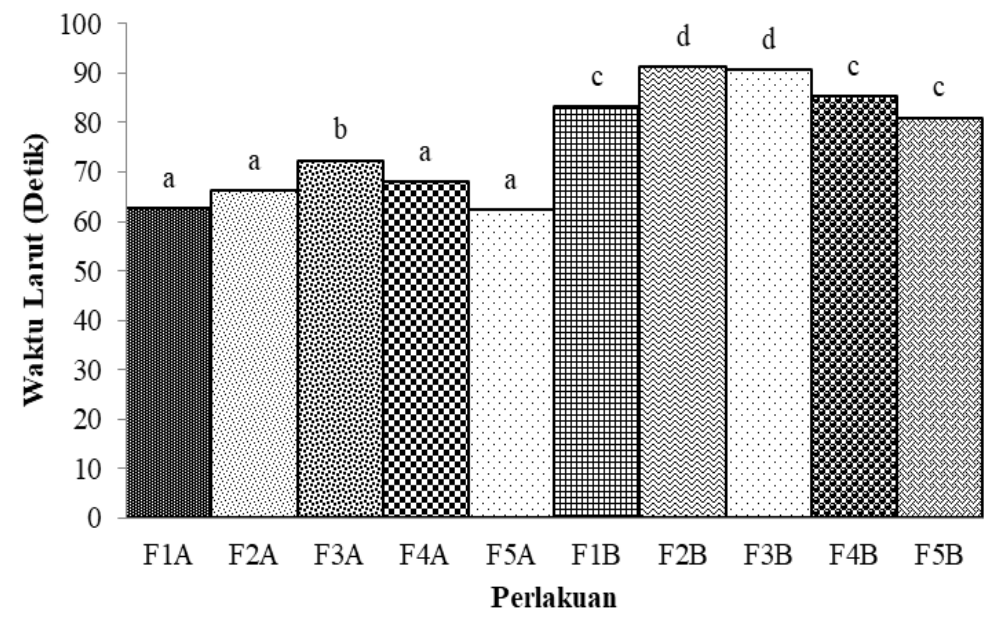

Gambar 5. Diagram Waktu Larut Granul Effervescent Ekstrak Daun Mangrove

Keterangan : huruf superscript yang sama pada diagram menunjukkan tidak ada perbedaan signifikan antara waktu larut dengan formulasi dan jenis spesie daun bakau $(\mathrm{P}>0,05)$

$\begin{array}{llll}\text { F1A } & : & \text { R. mucronata formulasi 1 } & \text { F1B: A. officinalis formulasi } 1 \text { sesuai Tabel } 1 \\ \text { F2A } & : & \text { R. mucronata formulasi } 2 & \text { F2B: A. officinalis formulasi } 2 \text { sesuai Tabel } 1 \\ \text { F3A } & : & \text { R. mucronata formulasi 3 } & \text { F3B: A. officinalis formulasi } 3 \text { sesuai Tabel } 1 \\ \text { F4A } & : & \text { R. mucronata formulasi 4 } & \text { F4B: A. officinalis formulasi } 4 \text { sesuai Tabel } 1 \\ \text { F5A } & : & \text { R. mucronata formulasi 5 } & \text { F5B: A. officinalis formulasi 5 sesuai Tabel } 1\end{array}$

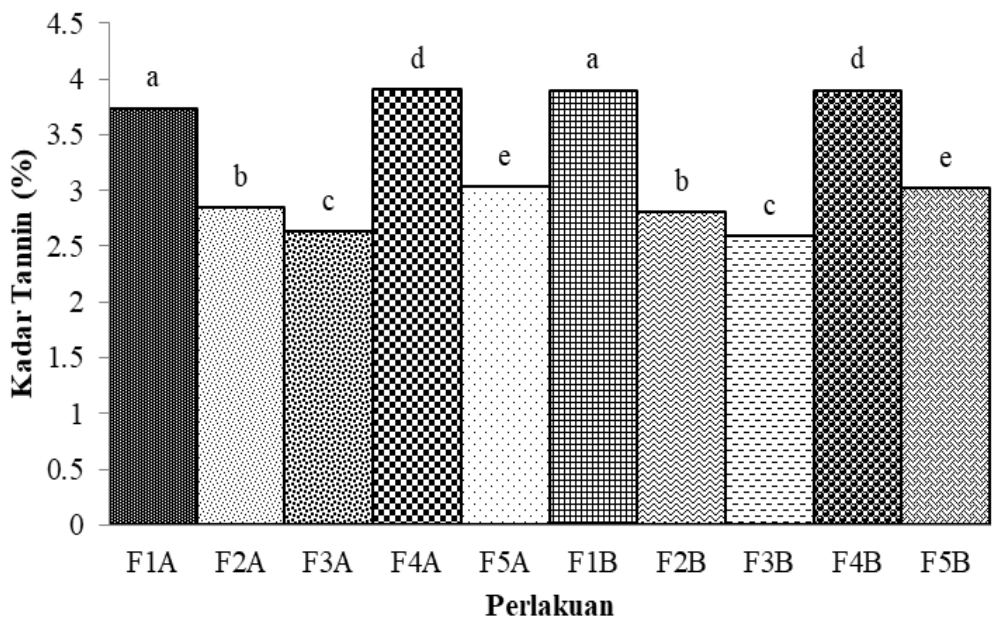

Gambar 6. Diagram Kadar Tanin pada Granul Effervescent Ekstrak Daun Mangrove

Keterangan : huruf superscript yang sama pada diagram menunjukkan tidak ada perbedaan signifikan antara nilai kadar tanin dengan formulasi dan jenis spesie daun bakau $(\mathrm{P}>0,05)$
F1A
R. mucronata formulasi 1
F1B: A. officinalis formulasi 1 sesuai Tabel 1
F2A
$R$. mucronata formulasi 2
F2B: A. officinalis formulasi 2 sesuai Tabel 1
F3A
R. mucronata formulasi 3
F3B: A. officinalis formulasi 3 sesuai Tabel 1
F4A
R. mucronata formulasi 4
F4B: A. officinalis formulasi 4 sesuai Tabel 1
F5A
$R$. mucronata formulasi 5
F5B: A. officinalis formulasi 5 sesuai Tabel 1 
Nirmala Efri Hasibuan et al.

JURNAL SAINS dan INOVASI PERIKANAN / Journal of Fishery Science and Innovation

Vol. 4 No. 2, 74-82 Juli 2020

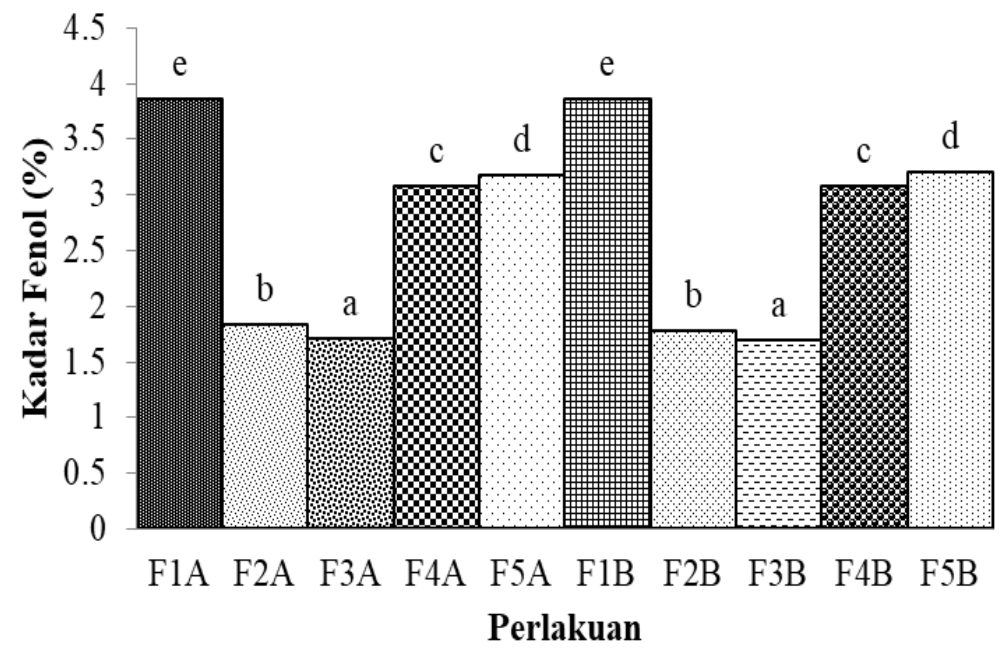

Gambar 7. Diagram Kadar Fenol pada Granul Effervescent Ekstrak Daun Mangrove

Keterangan : huruf superscript yang sama pada diagram menunjukkan tidak ada perbedaan signifikan antara nilai kadar fenol dengan formulasi dan jenis spesies daun bakau $(\mathrm{P}>0,05)$

$\begin{array}{llll}\text { F1A } & : & \text { R. mucronata formulasi 1 } & \text { F1B: A. officinalis formulasi } 1 \text { sesuai Tabel 1 } \\ \text { F2A } & : & \text { R. mucronata formulasi } 2 & \text { F2B: A. officinalis formulasi } 2 \text { sesuai Tabel 1 } \\ \text { F3A } & : & \text { R. mucronata formulasi 3 } & \text { F3B: A. officinalis formulasi } 3 \text { sesuai Tabel 1 } \\ \text { F4A } & : & \text { R. mucronata formulasi 4 } & \text { F4B: A. officinalis formulasi } 4 \text { sesuai Tabel 1 } \\ \text { F5A } & : & \text { R. mucronata formulasi 5 } & \text { F5B: A. officinalis formulasi 5 sesuai Tabel 1 }\end{array}$

Kadar air terendah dari formulasi tersebut adalah $2 \%$ pada F5B dan tertinggi adalah $2,8 \%$ pada F2A (Gambar 4). Hal ini sesuai dengan peraturan Badan Pengawas Obat dan Makanan (BPOM) tentang persyaratan keamanan dan mutu obat tradisional bahwa kadar air effervescent $\leq 5 \%$. Kailaku et al. (2012) membuat granul effervescent dari ekstrak gambir memperoleh kadar air 2,7\%. Kadar air akan mempengaruhi sifat fisik effervescent seperti kerapuhan dan proses pelarutan. Selain itu, kadar air berpengaruh pada daya simpan sediaan, kadar air yang terlalu tinggi menyebabkan serbuk effervescent menggumpal dan cepat berjamur /rusak (Septianingrum, et al., 2019).

Waktu larut granul effervescent yang digunakan untuk melarutkan granul secara sempurna di dalam air. Waktu larut effervescent berdasarkan peraturan $\mathrm{BPOM}$ adalah $\leq 5$ menit. Diagram waktu larut granul effervescent (Gambar 5) F1B-F5B yang mengandung ekstrak daun A.officinalis memiliki waktu larut yang lebih tinggi dari F1A-F5A yang berasal dari ekstrak daun R.mucronata. Perbedaan zat aktif yang terkandung pada ekstrak daun mangrove tersebut mempengaruhi waktu kelarutan granul effervescent. 1

Uji kadar tanin dan fenol sebagai kandungan senyawa metabolit sekunder pada daun mangrove.
Tanin merupakan senyawa metabolit sekunder polifenol yang terdapat pada tumbuhan tingkat tinggi. Tanin memiliki struktur molekul yang besar, mampu mengikat protein dan memiliki aktivitas antioksidan. Tanin berperan memperbaiki jaringan yang rusak pada permukaan kulit yang meradang atau luka bakar (Jaiswal et al., 2018).

Hasil uji kadar tanin granul effervescent daun mangrove berkisar antara 2,59 sampai 3,91\% (Gambar 6). Apabila kadar zat aktif suatu substansi tinggi maka sifat aktivitas antioksidannya juga meningkat. Takarina et al. (2016) memperoleh kandungan tanin pada daun mangrove Avicennia sp yang cukup tinggi mencapai $13,44 \%$. Senyawa tanin dimanfaatkan sebagai bahan obat medis. Sulmartiwi et al. (2018) menyatakan bahwa tumbuhan mangrove jenis $A$. rumphiana mengandung senyawa fenol, flavonoid dan tanin pada daun, buah dan akar. Senyawa tanin tertinggi diperoleh pada bagian buah yaitu 74,63 mg/g dan berperan sebagai antioksidan dengan nilai $\mathrm{IC}_{50} 232,43 \pm 1,43 \mathrm{ppm}$. Begitu pula dengan jenis mangrove $R$. mucronata dinyatakan sebagai agen antioksidan berdasarkan nilai $\mathrm{IC}_{50}$ 438.84 ppm (Mahmiah, 2016).

Hasil penelitian menunjukkan kenampakan buih masih sedikit terlihat pada permukaan larutan 
Nirmala Efri Hasibuan et al.

JURNAL SAINS dan INOVASI PERIKANAN / Journal of Fishery Science and Innovation

Vol. 4, No. 2, 74-82, Juli 2020

effervescent sedangkan perbedaan penambahan komposisi ekstrak daun mangrove mempengaruhi warna dan kejernihan dimana penambahan ekstrak $15 \%(\mathrm{~F} 1, \mathrm{~F} 2, \mathrm{~F} 3)$ dan 20\% (F4 dan F5), semakin tinggi penambahan ekstrak daun mangrove, maka kenampakan warna dan kejernihan larutan effervescent cenderung lebih pekat dan berwarna lebih tua, hal ini menunjukkan kadar tanin yang lebih tinggi. Hal ini sesuai dengan pernyataan Lestari et al., (2014) dan Mawardi et al. (2016) yang menyatakan bahwa apabila konsentrasi senyawa tanin pada daun tinggi maka warna ekstrak yang dihasilkan lebih pekat atau gelap. Faktor lain yang memberikan pengaruh terhadap warna air seduhan adalah senyawa flavonol dan theaflavin yang menghasilkan warna kuning.

Perbedaan spesies daun mangrove yang digunakan menunjukkan bahwa larutan effervescent dari daun mangrove A.officinalis (Formula B) menunjukkan warna lebih kemerahan sedangkan pada $R$. mucronata berwarna lebih hijau-kecoklatan. Menurut Mabruroh (2015), tanin berwarna putih kekuningan sampai coklat terang. Menurut Soenardjo dan Supriyantini (2017) bahwa tanin bersifat larut dalam air sehingga tanin akan terurai dalam air ketika ditambahkan air.

Kadar senyawa fenol dalam granul effervescent ekstrak daun mangrove mencapai 3,86\% (Gambar 7). Senyawa fenol ditemukan sebagai alternatif antioksidan alami. Maqsood, et al (2014) menggunakan senyawa fenol dan ekstrak fenol tumbuhan sebagai bahan antioksidan yang mampu menghambat oksidasi lipid pada makanan laut. Tanase, et al (2019) menyatakan bahwa senyawa polifenol dari tumbuhan merupakan sumber bioaktif yang dapat dimanfaatkan sebagai antioksidan, imunostimulan dan antibakteri.

\section{KESIMPULAN}

Hasil penelitian menunjukkan tidak ada perbedaan signifikan perbedaan spesies daun mangrove A.officinalis dan R.mucronata terhadap karakteristik serbuk effervescent sedangkan formulasi yang berbeda menunjukkan perbedaan signifikan dari karakteristik serbuk effervescent daun mangrove. Kelima formulasi memenuhi syarat evaluasi granul effervescent. Selain itu konten fenol dan tanin cukup tinggi pada daun mangrove sehingga berpotensi digunakan sebagai alternatif minuman segar dan sehat.

Ucapan Terima Kasih : Terima kasih penulis ucapkan kepada semua pihak yang telah membantu penyelesaian artikel ini.

\section{DAFTAR PUSTAKA}

Badan Pengawas Obat Dan Makanan.Peraturan Badan Pengawas Obat Dan Makanan Nomor 32 Tahun 2019 Tentang Persyaratan Keamanan Dan Mutu Obat Tradisional. Tahun 2019. Jakarta

Chanwitheesuk A, Teerawutgulrag A, Rakariyatham N. 2004. Screening of Antioxidant Activity and Antioxidant Compounds of Some Edible Plants of Thailand. Food Chemistry.92, 491-497.

Dhianawaty D, Ruslin. 2015. Kandungan Total Polifenol dan Aktivitas Antioksidan dari Ekstrak Metanol Akar Imperata cylindrica (L) Beauv. (Alang-alang). Journal Majalah Kedokteran Bandung. 47 (1):60-64

Egeten KR, Yamlean PVY, Supriati HS. 2016. Formulasi dan Pengujian Sediaan Granul Effervescent Sari Buah Nanas (Ananas comosus L. (Merr.)). Jurnal Ilmiah Farmasi - UNSRAT 5(3):116-121

Handayani S. 2013.Kandungan Flavonoid Kulit Batang dan Daun Pohon Api-api (Avicennia officinalis (Forks.)Vierh.) sebagai Senyawa Aktif Antioksidan. Skripsi. Instititut Pertanian Bogor

Jaiswal H, Singh OJ, Chauhan A, Sahu MK, DV SH. 2018. A Review On Tannins. EUROPEAN Journal of Biotechnology and Bioscience. 6 (3):16-17

Kailaku SI, Sumangat J, Hernani. 2012. Formulasi Granul Efervesen Kaya Antioksidan dari Ekstrak Daun Gambir. Journal Pascapanen 9(1) 2012: 27 $-34$

Kartikasari SD, Murti YB, Mufrod.2015. Formulasi Tablet Efferfescent Ekstrak Rimpang Jahe Emprit (Zingiber officinale Rosc.) dengan Variasi Kadar Asam Sitrat dan Asam Tartrat. Traditional Medicine Journal, 20(2): 119-126

Lachman J, Sulc M, Sus J. Pavlikova O. 2006. Polyphenol content and antiradical activity in different apple varieties. Horticultural Science 33: 95-102. 
Nirmala Efri Hasibuan et al.

JURNAL SAINS dan INOVASI PERIKANAN / Journal of Fishery Science and Innovation Vol. 4 No. 2, 74-82 Juli 2020

Lazuardi M. 2019. Bagian Khusus Ilmu Farmasi Veteriner Edisi 1. Airlangga University Press, Surabaya

Lestari P, Wijana S, Putri WI. 2014. Ekstraksi Tanin dari Daun Alpukat (Persea americana Mill.) sebagai Pewarna Alami (Kajian Proporsi Pelarut dan Waktu Ekstraksi). Jurusan Teknologi Industri Pertanian Universitas Brawijaya, Malang.

Mabruroh AI. 2015. Uji Aktivitas Antioksidan Ekstrak Tanin dari Daun Rumput Bambu (Lophatherum gracile Brongn) dan Identifikasinya. Skripsi. UIN Maulana Malik Ibrahim. Malang

Mahmiah, Giman, Aminah NS, Tanjung. 2016. Antioxidant Activity of Methanol Extracts From The Stem Bark Of Mangrove Plant Rhizophora mucronata. Proceeding ICMHS 47-50

Maqsood S, Benjakul S, Abushelaibi A, Alam A. 2014. Phenolic Compounds and Plant Phenolic Extracts as Natural Antioxidants in Prevention of Lipid Oxidation in Seafood: A Detailed Review. Comprehensive Reviews in Food Scienc and Food Safety, Vol 13:1125-1139

Mawardi YSA, Pramono YB, Setiani BE. 2016. Kadar Air, Tanin, Warna dan Aroma Off-Flavour Minuman Fungsional Daun Sirsak (Annona Muricata) dengan Berbagai Konsentrasi Jahe (Zingiber Officinale). Jurnal Aplikasi Teknologi Pangan 5 (3): 94-98

Mikchaell P, Eddy S, Hardoko. 2018. Antibacterial compounds Activity of Mangrove Leaf Extract Rhizophora mucronata on Aeromonas Hydrophyla. RJOAS, 1(73): 187-193

Noor YR, Khazali M, Suryadiputra INN. 2006. Panduan Pengenalan Mangrove di Indonesia. Wetlands International Indonesia Programme. Bogor: Ditjen PHKA.

Puspitasar YE, Hartiati AM, Suprayitno E. 2012. The Potency of Rhizophora mucronata Leaf Extract as Antidiarrhea. Journal of Applied Sciences Research, 8(2): 1180-1185

Ridlo A, Pramesti R, Koesoemadji, Supriyantini E, Soenardjo N. 2017. Aktivitas Antioksidan Ekstrak Daun Mangrove Rhizopora mucronata. Buletin Oseanografi Officinalis Oktober 2017 Vol 6 No 2:110-116

Soenardjo N, Supriyantini E. 2017. Analisis Kadar Tanin Dalam Buah Mangrove Avicennia marina Dengan Perebusan Dan Lama Perendaman Air
Yang Berbeda. Jurnal Kelautan Tropis November 2017 Vol. 20(2):90-95

Romantika RC, Wijana S, Perdani CG. 2017. Formulasi dan Karakteristik Tablet Effervescent Jeruk Baby Java (Cytrus sinensis L. Osbeck) Kajian Proporsi Asam Sitrat. Jurnal Teknologi dan Manajemen Agroindustri 6(1): 15-21

Septianingrum NMAN, Hapsari WS, Amin MK. 2019. Formulasi Dan Uji Sediaan Serbuk Effervescent Ekstrak Okra (Abelmoschus Esculentus) Sebagai Nutridrink Pada Penderita Diabetes. Jurnal Media Farmasi16(1):11-20

Setiana IH, Kusuma ASW. 2018. Review Jurnal Formulasi Granul Effervescent Dari Berbagai Tumbuhan. Jurnal Farmaka, Suplemen, 16(3):100-105

Sulmartiwi L, Pujiastuti DY, Tjahjaningsih W, Jariyah. 2018. Potential of Mangrove Avicennia rumphiana Extract as an Antioxidant Agent Using Multilevel Extraction. IOP Conf. Series: Earth and Environmental Science 137: 1-6

Syamsul ES, Supomo. 2014. Formulasi Serbuk Effervescent Ekstrak Air Umbi Bawang Tiwai (Eleuterine Palmifolia ) Sebagai Minuman Kesehatan. Traditional Medicine Journal, 19(3):113-117

Takarina ND, Patria MP. 2016. Content of Polyphenol Compound in Mangrove and Microalga Extracts. International Symposium on Current Progress in Mathematics and Sciences. AIP Conference Proceeding

Tanase C, Cosarca S, Muntean DL. 2019. A Critical Review of Phenolic Compounds Extracted from The Bark of Woody Vascular Plants and Their Potential Biological Activity. Molecules 24:1182

Wahyuni WT, Darusman LK, Surya NK. 2015. Potency of Rhizophora sp. Extracts as Antioxidant and Inhibitor of Acetylholinesterase. Procedia Chemistry, $16: 681-686$

Winarno. 2002. Kimia Pangan dan Gizi. Gramedia Pustaka Utama, Jakarta 